\title{
Occupational Mobility Among the Kaivarttas (Fisherman Community) in a Village Setting
}

\author{
Nobin Chandra Das, Dilip Das
}

\begin{abstract}
Kaivarttas are one of the major fishing communities of Assam. In the last few decades, the processes like globalization of marketing, liberalization of different policies and privatization of education have changed the life style of the Kaivarttas, not only in an urban area but village too. Now, they are engaged in different areas occupations including government, private and entrepreneurial works. As the occupation is closely interrelated with socio-economic and cultural factors, therefore, it is important to make a study to understand their adoption of new occupation in response to the process of social change. Present study is undertaken into two Kaivartta populated village in Majuli Island to understand the occupational mobility among them. The study shows that most of the villagers have taken up new occupations rather than fishing.

Key Words: Scheduled Caste, Kaivartta, Occupational Change, Assam, Majuli
\end{abstract}

\section{INTRODUCTION}

Occupation is a set of activities, associated with the livelihood of an individual. It is role perform by the individuals within society which is defined by the nature of work. An occupation has functional important and multiple consequences for the individual and society as stated by R.H. Hall (1975) in his book "Occupations and the Social Structure". In ancient Indian Hindu social system caste is closely related with occupation, the then, lower caste (Scheduled caste) people associated with some unclean and menial occupations. Scheduled caste people were able to grab the opportunity to mobilize their occupation due to spread of modern education, reservation policy in education and employment and so on. The concept "Occupational mobility" comes into existence in the field of Sociology that refers the process of movement from one occupational category to another. It involves charges in occupational attributes as locus, function, income, prestige's and power. The concept of occupational mobility can be study from diverse perspective of its various dimension i.e., rates, causes, processes or consequences. These dimensions are revealing about the nature of social structure and the influences upon attitudes and behaviour (Western, 2006). Occupational mobility among Kaivartta (fisherman community) is an important area hence the present paper attempts to emphasis of vertical occupational mobility of the Kaivartta community.

Revised Manuscript Received on January 03, 2020.

* Correspondence Author

Nabin Chandra Das*, Assistant Teacher, Majuli, Assam, Email: dnabin4@gmail.com dasdilip499@gmail.com

(c) The Authors. Published by Blue Eyes Intelligence Engineering and Sciences Publication (BEIESP). This is an open access article under the CC BY-NC-ND license (http://creativecommons.org/licenses/by-nc-nd/4.0/)
Dilip Das, Assistant Teacher, Lakhimpur, Assam, Email:

\section{THE KAIVARTTAS}

The Kaivarttas are one of the sixteen scheduled caste people of Assam and fishing and fish selling is their traditional occupation. They lived on river bank or near sources of water where they can catch fish. The origin and migration of the Kaivarttas to the river island is still shrouded with mystery. The earliest reference of the Kaivartta is found in the great epic Mahabharata. There are various shades of opinion regarding etymology of the word Kaivartta. Some scholars' opinion that the word 'Kaivartta' is Sanskritized from the prakit word 'Kevatta' which is composing of two words 'Ke' and 'Vatta', Ke means water and Vatta means living hood.

The Kaivarttas are found in almost all places of Majuli live in their own exclusive villages. According to census report 2011total population of Majuli distric is 167,304. Out of which 23,878 i.e. $14.3 \%$ of the total is Kaivartta people.

\section{OBJECTIVES}

Present study is an attempt to understand the changes take place in occupational dimension of the fishermen community in respect of the process of social change. The paper also focuses what are new occupations they were adopted and what are the factors responsible for adopting new earning source for their livelihood.

\section{METHODOLOGY}

The present study concerns only two villages namely Deka Senchowa and Malaphindha Kaivartta of Majuli district, Assam. There are two blocks in Majuli district namely Majuli Development Block and Ujani Majuli Development Block and from each block one village is selected purposively selected for the study. There are 254 families in the two villages. Every households of the village is taken as a unit of the study and head of the family were regard as respondent. Data are collected from both primary and secondary sources. Primary data are collected through structured interview schedule through survey. Books, Journals, Government records and census are use as a secondary data. The study has analysis empirical data in comparative perspective of occupational mobility of the Kaivartta community in a village setting of Majuli district and findings are drown by analysing average of two generation occupational position through table.

Published By:

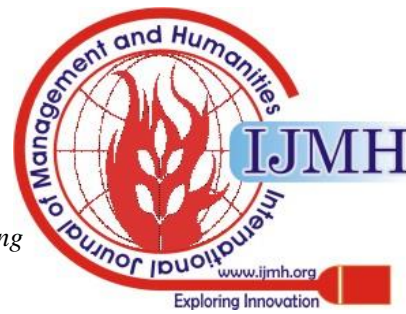




\section{RESULT AND DISCUSSION}

Occupational mobility, as nomenclature depicts, is change in traditional occupation of members of a society in order to earn their livelihood. Such occupational changes are mainly in terms of changes in distribution of their activities in socio-economic structure of a society. Kaivarttas, which constitute predominant scheduled caste community in the Brahmaputra valley of Assam, are traditionally fishermen by profession. But the contemporary Kaivartta society is passing through a process of change and the occupational structure is under the process of transformation.

In order to assessing the occupational mobility the data were collected from two generations and only the respondents had answered for the both. Table 1 reveals the trend of occupational mobility among them. Most of the Kavarttas switch over to cultivation (44.09\%). The cultivators of the village are living hand to mouth as their paddy lands are scarce. They are adopting business (9.45\%) as ways of their livelihood. In this group respondent it found that they are holding small and medium size business such as grocery shop, stationary shop, and cycle repairing and furniture shop. A few percentages of educated Kaivarttas are engaged in service (12.99) like teacher, army service, clerical and other department employee of the government and other private sectors.

Table 1: Occupation of Respondents

\begin{tabular}{|l|c|c|}
\hline \multicolumn{1}{|c|}{ Occupation } & Respondent & Percentage \\
\hline Fishing & 29 & 11.42 \\
\hline Fish selling & 18 & 7.08 \\
\hline Cultivation & 112 & 44.09 \\
\hline Business & 24 & 9.45 \\
\hline $\begin{array}{l}\text { Service (Govt. Semi- } \\
\text { govt. and private) }\end{array}$ & 33 & 12.99 \\
\hline Any Other & 38 & 14.97 \\
\hline Total & 254 & $100 \%$ \\
\hline
\end{tabular}

Source: Field Study during $5^{\text {th }}$ Oct-28 Dec, 2017

*Any Other: Wage earner, Carpenter, Driver

A few of them continue their forefather occupation i.e. fishing (11.42\%) and fish selling (7.08\%) while $14.97 \%$ people engaged in any other occupation category as their present occupation along with agricultural activities.

In the same way, it has been traced out the occupation of the respondent's father's generation for assessing occupational mobility. It is observed that tangency of occupational mobility also exist in respondent's father generation.

Table 2: Occupation of Respondents Father

\begin{tabular}{|l|c|c|}
\hline \multicolumn{1}{|c|}{ Occupation } & Father & Percentage \\
\hline Fishing & 88 & 34.65 \\
\hline Fish Selling & 42 & 16.53 \\
\hline Cultivation & 79 & 31.10 \\
\hline Business & 9 & 3.55 \\
\hline $\begin{array}{l}\text { Service (Govt., } \\
\text { Semi-govt. and } \\
\text { Private) }\end{array}$ & 7 & 2.75 \\
\hline Any Other & 29 & 11.42 \\
\hline \multicolumn{1}{|c|}{ Total } & 254 & $100 \%$ \\
\hline
\end{tabular}

Source: Field Study during $5^{\text {th }}$ Oct-28 Dec, 2017
The data indicate that majority of father generation pursuing fishing (34.65\%) occupation while $16.53 \%$ is found engaged in fish selling for their livelihood. Among the respondents father $31.10 \%$ depend exclusively on agriculture without any subsidiary income source where only $3.55 \%$ and $2.75 \%$ depend on business and service respectively. 29 respondents i.e. 11.42\% of respondent's father were engaged in any other occupation.

To make more specific of the study generation wise occupational position is need to be mention. Table 3 depicts the generation's wise occupational position and occupational mobility of the Kaivarttas under studied.

Table 3: Generation Wise Occupational Mobility

\begin{tabular}{|l|c|c|}
\hline Occupation & Father & Respondent \\
\hline Fishing & $88(34.65)$ & $29(11.42)$ \\
\hline Fish Selling & $42(16.53)$ & $18(7.08)$ \\
\hline Cultivation & $79(31.10)$ & $112(44.09)$ \\
\hline Business (Govt., & $9(3.55)$ & $24(9.45)$ \\
\hline $\begin{array}{l}\text { Service } \\
\text { Semi-govt., Private) }\end{array}$ & $29(11.42)$ & $33(12.99)$ \\
\hline Any Other & $254(100 \%)$ & $254(100 \%)$ \\
\hline Total & \\
\hline \multicolumn{2}{|l|}{ Source: Field Study during $5^{\text {th }}$ Oct-28 Dec, 2017} \\
\hline
\end{tabular}

Source: Field Study during $5^{\text {th }}$ Oct-28 Dec, 2017

It can be interred from Table 3, the occupation of two successive generations, $34.65 \%$ fathers were solely depended on fishing occupation followed by $16.53 \%$ were pursued fish selling as main source of living. But in the generation of respondent though it is not entirely different from the father generation, the traditional occupation is gradually declining among them. In the respondent generation, it is found only $11.42 \%$ are pursued fishing whereas $7.08 \%$ are resorted to fish selling. These occupational positions of the two generations show a declining trend of traditional occupation.

The study reveals a clear tendency in general to move away from traditional occupation to different occupations opened up in recent age. Occupational position of the two generations reflects a picture of occupational mobility among the Kaivarttas under study. In this context several factors are responsible in shifting of occupation from traditional fishing and fish selling to new one. This are-

1. Emergence of modern education among younger generation opens their eyes for new avenues of livelihood.

2. Fishing needs hard labour. Though they were labour hard, due to unavailability of fishes, exploitation of middleman, lack of modern equipment prevents sufficient income to maintain their family.

3. Most of the marshy land, river, beels near the village have been taken over by the government and leaseholders got the extreme power. Term and conditions of the Mahaldars are also not satisfactory to them.

4. Society's attitude towards fishing and fish trading compels the younger section to seek other profession.

\section{Published By:}

\& Sciences Publication

(C) Copyright: All rights reserved.

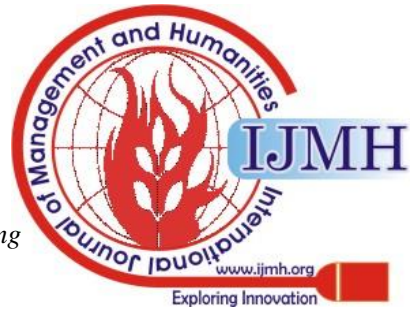


5. Earlier it was only the Kaivarttas who catching and selling fishes, but at present it is found in Majuli the Misings and other no-Kaivarttas people are engaged in this profession. So, they were less benefited.

\section{CONCLUSION}

The survey reveals that the Kaivarttas of the Majuli Island, who were traditionally fisherman, are gradually declining their forefather occupation. Reasons for such change in their traditional occupation are of both internal and external. Internal reasons are mainly due to psychological factors such as enthusiasm of people to assemble a better life, inferiority complex of younger people since profession is considered as derogatory and urge of people to enhance their social recognition in broader society. External forces are also playing an important role in bringing a change in traditional profession of villagers either by creating barriers to pursue their existing profession or by offering them opportunities to shift themselves into a better profession than their traditional profession.

External forces that are creating barriers and forcing the villagers to shift themselves to some other occupations i.e. low profit margin of fish trading more particularly during summer seasons, dwindling of sources of fish since most of beels and fisheries have been taken over by Government and the terms and conditions of the Leaseholders (Mahalders) are not satisfactory, negative attitude of society towards fish selling etc.

On other hand external forces which offer opportunities to villagers to shift themselves into a better profession include building of school and college due to which education is spreading in the village and educated people are reluctant to follow their traditional occupation. Besides provision for better educational facilities to villagers, advanced communication technology, governmental policies and programmes, banking facilities, and modern agricultural equipment etc., are enhancing villages to opt for a better occupational opportunity.

\section{REFERENCES}

1. K. C. Mahanta, A diachronic study of change and development in three Kaivartta villages of Assam. In Core problems of the scheduled castes of Assam, B. K. Hazarika, Ed. Guwahati: Assam Institute of Research for Tribal's and Scheduled Castes, 1995, pp. 34-37.

2. R. P. Athparia, D. N. Pandey, "Victims of poverty: A case study of the scheduled castes of Assam", In Population, poverty and environment in north-east India, B. Dutta Ray \& et. Al, Ed. New Delhi: Concept Publishing Company, 2000, pp.343-348.

3. N. Bania, "Identification of existing occupation of scheduled castes people and problems connected with their improvement and upgradation", In Core problems of the scheduled castes of Assam, B. Kr. Hazarika, Ed. Guwahati: Assam Institute of Research for Tribal's and Scheduled Castes, 1995, pp. 29-33.

4. J. K.Borgohain, "Anusuchivukta sampadayar arthik unnyanr sayambhana", In Core problems of the scheduled castes of Assam, B. Kr. Hazarika, Ed, Guwahati: Assam Institute of Research for Tribal's and Scheduled Castes, 1995, pp. 151-155.

5. B. N. Bordoloi, Socio-economic conditions of the Kaivarttas of Assam: A case study, Guwahati: Assam Institute of Research for Tribal's and Scheduled Castes, 1994, ch. 7.

6. B. Das, A glimpse of the scheduled caste and their socio-economic development in Assam, New Delhi: Omsons Publications, 1986, ch. 4

7. B. J. Dev, D. K. Lahiri, Cosmogony of caste and social mobility in Assam, Delhi: Mitali Publication, 1984, ch.5

8. R. Firth, Malay fishermen: Their economy and peasantry, $2^{\text {nd }}$ edition, London: Routledge and Kegan Paul, 1966, pp. 245-248
9. E. A. Gait, A history of Assam, $2^{\text {nd }}$ edition (Reprint), Guwahati: Lawer's Book Stall, 1926.

10. R. H. Hall, Occupation and the social structure. prentice hall of India, Engle Wood Clifts, New Jessery,1975, pp. 4-5.

11. S. Immanuel, G. S. Rao, Profile of a fishing community in Andhra Pradesh. Social Action, 2008, 58(1), pp. 49-58.

12. D. Nath, The Majuli island: Society, economy and culture, Delhi: Anshah Publishing House, 2009, pp.203-237.

13. H. H. Risley, 1891 The tribes and castes of Bengal. Culcutta, Bengal secretariat press, Vol. I, 1981, pp. 375-382.

14. S. Sachchidananda, "Research on scheduled castes with special reference to change: A trend report", In A survey of research in sociology and social Anthropology, vol. 1, M. N. Srinivas, M. Sarao, A. M. Shah, Ed. Bombay: Popular Prakashan, 1974, pp. 281.

15. J. M. Acheson, (2017, June). Anthropology of fishing, Annual Review of Anthropology: Annual Review, 10 pp. 275-316. http://www.jstor.org/stable/2155719

\section{AUTHORS PROFILE}

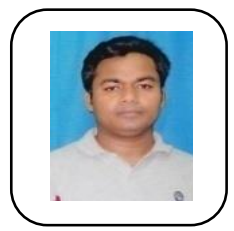

Nobin Chandra Das, He was born in Majuli on 28 February, 1983. He pursued graduation in department of Sociology, Pub Majuli College, Majuli and then obtains M.A. in Sociology from Dibrugarh University, Dibrugarh. He has completed Doctor of Philosophy from Assam University, Silchar (A Central University, Act 1989) under supervisor

of Dr. Nirakar Mallick on the topic "The Kaivarttas in Majuli: An Ethnographic Study". He has around four years teaching experiences as assistant professor in the department of Sociology of Mahatma Gandhi University (private), Meghalaya. He has 7 publications having ISSN\&ISBN in international journal and edited book. He has permanent membership in Indian Sociological Society, India. Now, he is working as assistant teacher in a government school under Assam Government. He has also pursued D. El. Ed (NIOS).

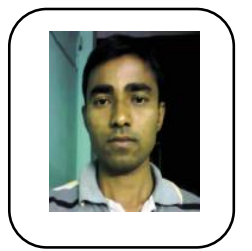

Dilip Das, He was born in Majuli on 1 Feb, 1983. He pursued graduation in department of Assamese from Majuli College, Majuli and then obtains M.A. in Assamese from Dibrugarh University, Dibrugarh. He has completed Master of Philosophy from Assam University, Silchar (A Central University, Act 1989) under the supervisor of Dr.Kusumbar Barouah.

He has around two years teaching experiences as assistant professor in the department of Assamese of Tingkhung College, Dibrugarh. He has 5 publications having ISSN\&ISBN in international journal and edited book. Now, he is working as assistant teacher in a government school under Assam Government. He has also pursued D. El. Ed (NIOS).

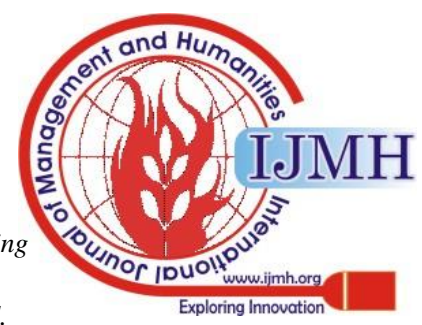

